\title{
ENFORCING THE ROME STATUTE: EVIDENCE OF (NON) COMPLIANCE FROM KENYA
}

\author{
Yvonne M. Dutton*
}

\section{INTRODUCTION}

In July 1998, with the adoption of the Rome Statute, states created the world's first permanent international criminal court, the International Criminal Court (ICC). ${ }^{1}$ The ICC began its work in The Hague in 2002. The court's stated ambition, according to the preamble of the Rome Statute, is to end impunity for perpetrators of genocide, crimes against humanity, war crimes, and aggression. $^{2}$ States did not take the court's ambition lightly: they endowed the institution with strong powers. According to treaty terms, the more than 120 states that have already committed to the court agree that an independent prosecutor may try a state’s own nationals for mass atrocities, should the ICC determine that the state is unwilling or unable to do so domestically. ${ }^{3}$ The prosecutor and court operate without direct United Nations Security Council oversight. ${ }^{4}$ Moreover, the treaty does not recognize any immunity for heads of state. ${ }^{5}$ Of course, the ICC is not allpowerful: for example, it has no police force and must rely on states to execute on its arrest warrants. But on the whole, the ICC has been designed so that the looming and real threat of prosecution should induce compliance with treaty terms.

But is the ICC actually effective in enforcing compliance and positively influencing behavior? To date, the evidence on the effectiveness of international human rights treaties in

\footnotetext{
* Associate Professor, Indiana University Robert H. McKinney School of Law. Thanks to Eamon Aloyo, George Edwards, and Stuart Ford for commenting on earlier drafts.

${ }^{1}$ U.N. Rome Statute of the International Criminal Court, July 17, 1998, U.N. Doc. A/CONF. 183/9 (1998).

${ }^{2}$ Id. at preamble, article 5.

${ }^{3}$ Id. at Arts. 5-8, 11, 12(2), 13.

${ }^{4}$ Lionel Yee, The International Criminal Court and The Security Council: Articles 13(b) and 16, in ROY S. LEE, THE INTERnATIONAL CRIMINAL COURT: THE MAKING OF THE ROME STATUTE 143-52 (1999).

${ }^{5}$ U.N. Doc. A/CONF. 183/9, supra note 1 at Art. 27.
} 
improving behavior is mixed at best. ${ }^{6}$ Some studies, in fact, conclude that that treaty commitment does not contribute to better state practices. ${ }^{7}$ The treaties that are the subject of those studies, however, have weak enforcement mechanisms: they only require states to self-report the compliance and measures they have undertaken to implement treaty terms and improve their domestic protections against human rights abuses. ${ }^{8}$ As commentators have noted, this lack of any real enforcement mechanism means that some states can choose to commit without facing any specific negative consequences should they fail to comply. ${ }^{9}$ The ICC, by contrast, can try the citizens of member states (and even the citizens of non-member states under some circumstances) if they commit mass atrocities.

If the ICC's powers are as strong in practice as they are on paper, should we not expect more promising findings? This Article examines Kenya's relationship with the ICC for evidence of whether the ICC is effective at holding states accountable to their commitment to the Rome Statute and the stated goal of ending impunity for mass atrocities. Kenya has a history of poor human rights practices and violent domestic conflict. Yet it joined the court in 2005 and became the subject of the ICC's prosecutor's first proprio motu prosecution. Examining the Kenya case

\footnotetext{
${ }^{6}$ See, e.g., Linda Camp-Keith, The United Nations International Covenant on Civil and Political Rights: Does It Make a Difference in Human Rights Behavior?, 36 J. PEACE RES. 95 (1999) (finding no empirical evidence suggesting that commitment to the International Covenant on Civil and Political Rights improved states' human rights practices); Daniel W. Hill, Jr., Estimating the Effects of Human Rights Treaties on State Behavior, 72 J. PoliTiCs 1161, 1170-71 (2010) (finding that states improved their relevant behavior after commitment to some international human rights

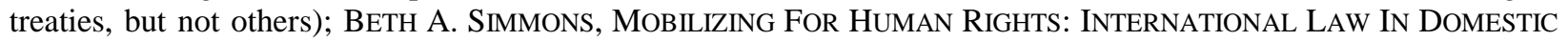
Politics 68 (2009), (finding that governments that are not stable democracies or autocracies do improve their respect for human rights after treaty ratification).

${ }^{7}$ See, e.g., Oona Hathaway, Do Human Rights Treaties Make a Difference, 8 YALE L. J. 1935, 1940 (2002) (finding that "noncompliance with treaty obligations appears to be common" and that in some cases ratification was "not infrequently associated with worse human rights ratings than otherwise expected").

${ }^{8}$ See Yvonne M. Dutton, Explaining State Commitment to the International Criminal Court: Strong Enforcement Mechanisms as a Credible Threat, 10 WASH. U. GLOBAL StUDS. L. ReV. 477, n.9 (2011) (citing to enforcement provisions of human rights treaties).

${ }^{9}$ See Emilie M. Hafner-Burton \& Kiyoteru Tsutsui, Human Rights in a Globalizing World: The Paradox of Empty Promises, 110 AM. J. Soc. 1373, 1374 (2005) (noting that the average state has ratified a steadily increasing number of human rights treaties, but that the percentage of states reportedly repressing human rights has grown over time, suggesting that states may ratify only as window dressing).
} 
should provide insights about the strength of the prosecutor's powers in practice and the prospects for future compliance with the ICC's proprio motu investigations-namely, those investigations that the prosecutor is empowered to commence without waiting for a state or United Nations Security Council referral. To the extent that the evidence shows an ICC without strong enforcement powers in practice, this timely study should aid policy makers and states in finding ways to ensure that this new institution can make the positive contribution to international justice its creators intended it to make.

This Article describes Kenya's commitment to the ICC and the subsequent ICC investigation into the Kenyan situation. The next section outlines the literature addressing the design of international human rights law treaties and their effectiveness in inducing compliance and positively influencing behavior. The Article then turns to describing methodology and examining the evidence of compliance (or lack thereof) with treaty terms and demands in the context of the ICC's case against Kenya. The Article concludes with some observations about the evidence and its implications regarding the ICC’s enforcement powers.

\section{BACKGROUND: KENYA AND THE ICC}

Kenya signed the ICC treaty on August 11, 1999, under the leadership of long-time authoritarian President Daniel arap Moi. ${ }^{10}$ It ratified the treaty in 2005, only three years after the election of President Mwai Kibaki-a politician who ran on a platform promising democratic reforms. ${ }^{11}$ When Kenya joined the court, it was still a country plagued by poor human rights practices and weak domestic law enforcement institutions. It also joined knowing that it had a

\footnotetext{
${ }^{10}$ Ballots to Bullets: Organized Political Violence and Kenya's Crisis of Governance, HumAN RighTs WATCH (17 Mar, 2008), Volume 20, No. 1 (A), available at http://www.refworld.org/docid/47de7bd22.html, at 16 (referencing Moi's term as president until 2002).

${ }^{11}$ See Andrew England, New President of Kenya Vows to End 'malaise:' Kibaki Sworn in, Pledges to Undo Years of Corruption, THE CHICAGO TRIBUnE, Dec. 31, 2002.
} 
history of significant ethnic violence leading up to or following elections. ${ }^{12}$ Nevertheless, Kenya ratified the Rome Statute at a time when President Kibaki was under significant pressure from both the international community and its own civil society to demonstrate his commitment to the democratic and judicial reforms he had promised during his campaign. Indeed, in 2005, the NGO Coalition for the International Criminal Court (CICC) chose Kenya as its target country on which to focus its ICC ratification efforts. ${ }^{13}$

Only a couple of short years after ratification, however, Kenya erupted into ethnicallycharged violence in the aftermath of its presidential elections. More than 1,000 people died - and some 300,000 were displaced - during the violence that occurred after Kibaki allegedly rigged election results which voting tallies had suggested were favoring his opponent, Raila Odinga. ${ }^{14}$ Only one hour after the Chair of the Electoral Commission of Kenya declared Kibaki the winner of the presidential elections, Kibaki quickly had himself sworn into office. ${ }^{15}$ Violence erupted shortly thereafter. Although reports suggest that some violence was spontaneous and some was orchestrated by Odinga supporters against the ethnic groups that supported Kibaki, the facts also show that Kibaki’s own police forces actually contributed to the violence that left more than one thousand people dead and hundreds of thousands displaced. ${ }^{16}$

\footnotetext{
${ }^{12}$ Ballots to Bullets, supra note 10.

${ }^{13}$ COALITION FOR THE INTERNATIONAL CRIMINAL COURT, GLOBAL COALITION CALLS ON KENYA TO RATIFY INTERNATIONAL CRIMINAL COURT TREATY: As CONFLICTS RAGE IN NEIGHBORING COUNTRIES, KENYA'S RATIFICATION CAN OFFER BEACON OF HOPE, (Jan. 11, 2005), available at http://www.coalitionfortheicc.org/documents/KenyaRat_11Jan05.pdf (after Kenya ratified the ICC treaty, it was by its own civil society for sending a strong message that it intends to break from its past cycle of impunity. Kenya National Commission on Human Rights, Ratification of International Criminal Court is an Essential Pillar for Securing the Rights of Kenya).

${ }^{14}$ Human Rights Watch, ORganized Political Violence and Kenya's Crisis of Governance, supra note 12, at $21-23$.

${ }^{15} I d$. at 22.

${ }^{16}$ U.N. High Comm. for Human Rights Rep. from OHCHR Fact-finding Mission to Kenya, Feb. 6, 2008-Feb. 28, 2008, (2008), at 8-12.
} 
To address the violence, the international community helped to establish a mediation process led by former Secretary-General of the United Nations, Kofi Annan. The main outcome of that process was the formation of a grand coalition Government, with Kibaki as President and Odinga as Prime Minister. ${ }^{17}$ In addition, a Commission of Inquiry, chaired by Justice Philip Waki of the Kenyan Court of Appeal, was charged with investigating the post-election violence and making recommendations. The Commission’s report (the “Waki Report”) issued on October 15, 2008, concluded that there were systematic and violent attacks to kill and maim citizens based on their ethnicity and political affiliations. ${ }^{18}$ To break the country’s cycle of impunity surrounding post-election violence, the report recommended establishing a Special Tribunal in Kenya to investigate, prosecute, and adjudicate the identified alleged crimes. ${ }^{19}$ The Commission gave Kofi Annan a list of names to forward to the ICC in the event the Special Tribunal processes did not proceed. ${ }^{20}$

The Special Tribunal was never created. Hours before the initial deadline to send the list of names to the ICC, the government signed a bill to start the legislative process necessary to create the tribunal. ${ }^{21}$ However, the bill was later rejected by parliament. ${ }^{22}$ The deadline to turn over the

\footnotetext{
${ }^{17}$ See Kenyan National Dialogue and Reconciliation, The National Accord and Reconciliation Act (2008), available at http://www.dialoguekenya.org/docs/Signed_National_Accord_Act_Feb28.pdf. [http://perma.cc/7KKG-7KAK].

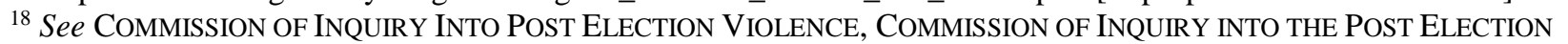
VIOLENCE (CIPEV) REPORT 347 (2008),

http://www.kenyalaw.org/Downloads/Reports/Commission_of_Inquiry_into_Post_Election_Violence.pdf

[hereinafter Waki Commission Report].

${ }^{19}$ L. Muthoni Wanyeki, The International Criminal Court's Cases in Kenya: Origin and Impact, INST. SEC. STUDIES, No. 237 (August 2012), at 7.

${ }^{20}$ Antonia Okuta, National Legislation For Prosecution Of International Crimes in Kenya, 7 J. INT’L CRIM. JusTICE 1063, 1065 (2009).

21 David Mugonyi, Secret List: Now Kibaki and Raila Sign Pact, Daily NaTiON (Dec. 17, 2008), http://www.nation.co.ke/News/-/1056/503642/-/view/printVersion/-/14c3qeg/-/index.html.

${ }^{22}$ Okuta, supra note 20, at 1069. (In fact, Kenya's parliament rejected a bill to establish a special tribunal on several occasions: on February 12, 2009, July 14, 2009, and July 30, 2009. On November 2009, parliament did not have a quorum to debate the special tribunal bill.) See Thomas Obel Hansen, Transitional Justice in Kenya? An Assessment of the Accountability Process in Light of Domestic Politics and Security Concerns, 42 CAL. W. INT'L L.J. 1, 8 (2011).
} 
names was extended more than once at Kenya's request. Yet parliament still voted down the bill to establish the Special Tribunal. ${ }^{23}$ As a result, the list of names was forwarded to the ICC prosecutor.

In November 2009, after the Kenyan government refused to self-refer its case to the ICC, the ICC prosecutor used his proprio motu powers for the first time to open a preliminary investigation into the post-election violence. ${ }^{24}$ In March 2010, an ICC Pre-Trial Chamber authorized the prosecutor to commence a formal investigation into the Kenya situation. In March 2011, the ICC issued summonses for six prominent Kenyans from Kibaki's and Odinga's political parties. ${ }^{25}$ Several weeks later, Kenya filed an application challenging the admissibility of the case, arguing that the country was in the process of a comprehensive judicial reform and intended to investigate and prosecute the case domestically. That challenge was rejected; the court concluded that Kenya had provided no credible information suggesting that it was in fact investigating the suspects. ${ }^{26}$ On January 23, 2012, the ICC confirmed charges against four of the six suspects, among them now-President Kenyatta and now-Deputy President Ruto (who assumed their posts in March 2013). ${ }^{27}$

As of January 2015, however, the ICC was proceeding against only two of the suspects. The ICC dropped its case against suspect Francis Muthaura (Head of Public Service and Secretary

\footnotetext{
${ }^{23}$ Maria Wambua, How Kenya Handled Local Tribunal Process, DAILY NATION (Sept. 17, 2013), http://www.nation.co.ke/news/politics/How+Kenya+handled+local+tribunal+process++/-/1064/1997172/-/iko52x//index.html.

${ }^{24} I d$. For a description of the ICC Prosecutor's proprio motu powers, see The Rome Statute, at Art. 15.

${ }^{25}$ Charles C. Jalloh, Commentary, Kenya vs. The ICC Prosecutor, 53 HARV. INT’L L.J. ONLINE, 269, 270-71 (2012).

${ }^{26}$ See Prosecutor v .William Samoei Ruto, Henry Kiprono Kosgey and Joshua Arap Sang, Case No. ICC-01/09-0111, Decision on the Application by the Government of Kenya Challenging the Admissibility of the Case Pursuant to Article 19(2)(b) of the Statute (May 30, 2011); Prosecutor v. Francis Kirimi Muthaura, Uhuru Muigai Kenyatta and Mohammed Hussein Ali, Case No. ICC-01/09-2/11, Decision on the Application by the Government of Kenya Challenging the Admissibility of the Case Pursuant to Article 19(2)(b) of the Statute (May 30, 2011).

${ }^{27}$ Wanyeki, supra note 19, at 15.
} 
to the Cabinet at the time of the post-election violence). ${ }^{28}$ In doing so, the prosecutor cited evidentiary difficulties, including problems related to the absence of witnesses because of deaths or refusals to testify because of fear. ${ }^{29}$ The case against Kenyatta met a similar fate in December 2014. ${ }^{30}$ The prosecutor said that dropping the charges constituted a "dark day" for international criminal justice, but stated that the case could not continue because Kenya had obstructed the court's investigation of Kenyatta, leading to a lack of sufficient evidence to prove guilt beyond a reasonable doubt. ${ }^{31}$ Trials against the two remaining defendants, Ruto and Joshua Arap Sang (Head of Operations at radio station, Kass FM) commenced in September 2013. The trial was ongoing as of early 2015, and had apparent evidentiary difficulties. As to the case against Ruto in particular, the prosecutor has stated, "[w]e are having tremendous difficulties, as usual, with our witnesses not wanting to come forward or changing their minds at the last minute.”32

\section{The Potential Effectiveness of The ICC In ENForcing CoMPliance With}

\section{TREATY TERMS}

Before analyzing the evidence of whether Kenya has "benefited" from its ICC commitment, this section briefly surveys the literature on the effectiveness of international human

\footnotetext{
${ }^{28}$ See International Criminal Court, STATEMENT By ICC PROSECUTOR ON THE NotiCE TO WITHDRAW CHARGES AGAINST MR MUTHAURA (2013), http://www.icccpi.int/en_menus/icc/press\%20and\%20media/press\%20releases/Pages/OTP-statement-11-03-2013.aspx. ${ }^{29}$ Michael Pearson \& Zain Vergee, ICC Drops Charges Against Former Kenya Official, CNN (March 11, 2013), http://www.cnn.com/2013/03/11/world/africa/kenya-icc-charges/index.html. [http://perma.cc/R77H-AGCJ].

${ }^{30}$ Marlise Simons \& Jeffrey Gettleman, International Court Ends Case Against Kenyan President in Election Unrest, N.Y. TIMES (Dec. 5, 2014), http://www.nytimes.com/2014/12/06/world/africa/uhuru-kenyatta-kenyainternational-criminal-court-withdraws-charges-of-crimes-against-humanity.html?_r=0. [https://perma.cc/W7B8UBCM].

${ }^{31}$ Carol J. Williams, “Dark Day”: Hague prosecutors drop charges against Kenyan leader, L.A. TIMES (Dec. 5, 2014), http://www.latimes.com/world/africa/la-fg-icc-kenya-kenyatta-charges-dropped-20141205-story.html. [http://perma.cc/Q7SQ-ZGR6].

${ }^{32}$ Kevin J. Kelley, Bensouda Cites Difficulties With Ruto Witnesses, DAILY NATION (May 14, 2014), http://www.nation.co.ke/news/Bensouda-cites-tremendous-difficulties-with-Ruto-witnesses/-/1056/2314088//j7khcx/-/index.html. [http://perma.cc/76YE-LLAM].
} 
rights treaties in inducing compliance and promoting better practices. Thus far, that literature has reached no absolute conclusions. Rather, scholars continue to debate whether and to what extent international human rights treaties can actually constrain state practices and improve domestic protections against human rights abuses.

For instance, scholars adhering to a realist tradition argue that international law has little effect on a state's human rights practices. ${ }^{33}$ Instead, states act rationally and are guided by selfinterest. They may improve their human rights practices, but not because a treaty requires them to do so. As Jana von Stein argued, treaties may screen out potentially bad and noncompliant members, rather than induce them to join and thereafter alter their behavior to conform to treaty terms. ${ }^{34}$

Other literature is more optimistic about the effects of treaty commitment. Scholars doing normative research emphasize states' innate "propensity to comply" with the agreements they sign. According to this theory, states genuinely wish to embrace change, and formal treaties provide them with the channels through which they may exercise this propensity. Thus, the institution acts to constrain state behavior because the states themselves are seeking a mechanism by which to commit to change. ${ }^{35}$

Scholars in the institutionalist tradition also argue that international institutions can, and do, favorably constrain and alter sovereign behavior. However, they emphasize how the state's particular domestic political situation may exert some pressure on the government to embrace the hand-tying effects of committing to an international institution. Indeed, Beth Simmons suggested

\footnotetext{
33 JaCK L. GOLDSMith \& ERIC A. Posner, THe Limits OF INTERNATIONAL LAW 121-24 (2005).

${ }^{34}$ Jana von Stein, Do Treaties Constrain or Screen? Selection Bias and Treaty Compliance, 99 AM. PoL. SCI. REV. 611 (2005).

${ }^{35}$ See generally A. Chayes \& A.H. Chayes, On Compliance, 47 INT’L ORG. 175 (1993).
} 
that by committing to an international legal institution, governments might send a credible signal to their domestic or international audiences about their intention to behave differently in the future under conditions of incomplete information and uncertainty. ${ }^{36}$ For example, states in democratic transition may have poor human rights practices, but may nevertheless wish to tie their hands through a human rights institution to help facilitate future improvement. ${ }^{37}$

A separate question is whether there is evidence to support these theories about the ability of international human rights institutions to constrain and improve state behavior. The evidence is equivocal. Several early empirical studies failed to find evidence demonstrating that treaty ratification caused an improvement in states’ human rights practices. ${ }^{38}$ A 2005 study by Emilie Hafner-Burton and Kiyoteru Tsutsui found that for states with the worst human rights practices, membership in the Convention against Torture (CAT) and the International Convention for the Protection of Civil and Political Rights (ICCPR) was no more likely to produce better behavior than had the states that remained outside the treaty. ${ }^{39}$ Daniel Hill's 2010 study found that states that committed to the Convention for the Elimination of Discrimination against Women improved their protection of women's political rights after commitment. With regard to the ICCPR and CAT, however, he found that commitment was associated instead with worse human rights practices. Hill hypothesized that states committing to the CAT and the ICCPR may commit "as a subterfuge to hide worsening practices.”40

\footnotetext{
${ }^{36}$ Beth A. Simmons, International Law and State Behavior: Commitment and Compliance in International Monetary Affairs, 94 Am. POL. SCI. REV. 819 (2000).

${ }^{37}$ See, e.g., Beth A. Simmons \& Alison Danner, Credible Commitments and the International Criminal Court, 64 INT'L ORG. 225 (2010); Andrew Moravcsik, The Origins of Human Rights Regimes: Democratic Delegation in Postwar Europe, 54 INT’L ORG. 225 (2000).

${ }^{38}$ See, e.g., Camp-Keith, supra note 6; Hathaway, supra note 7.

${ }^{39}$ Haftner-Burton \& Tsutsui, supra note 9.

${ }^{40}$ Hill, supra note 6 , at $1170-72$.
} 
By contrast, some scholars have found that membership in international human rights treaties can positively influence the behavior of some category of states: they have found that the positive effect is conditional on the presence of some other important factor. In their separate studies, both Beth Simmons and Eric Neumeyer concluded that the presence of an active civil society was a factor influencing whether or not treaty membership could successfully constrain states and lead to greater domestic protection of human rights. ${ }^{41}$

To date, there is scant literature testing the impact of the ICC and whether it is influencing behavior in a positive way as contemplated by the Rome Statute. On the other hand, that limited literature has produced some preliminary evidence suggesting that the ICC may have the positive influence and deterrent effect that scholars have frequently found lacking in their studies of other international human rights treaties. Specifically, using case studies of indictments for leaders in Côte d'Ivoire, Uganda, and Sudan; Payam Akhavan concluded that the ICC deters violence by raising the potential cost of it, rather than creating perverse incentives for leaders who have been indicted to continue committing human rights abuses to avoid arrest. ${ }^{42}$ Mitchell and Powell invoked an argument about domestic legal structures, finding that an ICC signature is mostly irrelevant, but that ratification reduces many forms of human rights abuses. ${ }^{43}$

\section{TESTING THE ICC’s EFFECTS ON COMPLIANCE In THE ConTEXT OF THE KENYA CASE}

Using Kenya as a case study, this section explores the outlined theories about the ability of

\footnotetext{
${ }^{41}$ Simmons' results showed that governments that were not stable democracies or autocracies improved their respect for human rights after ratification, a finding she attributed to the presence of an active civil society with an incentive to mobilize and demand improvements in state practices. See Simmons, supra note 36. Neumeyer, on the other hand, found that the more democratic a country was and the more active its civil society, the more likely it was to improve its practices after joining the CAT. Eric Neumeyer, Do International Human Rights Treaties Improve Respect for Human Rights?, 49 J. CONFLICT RES. 925, 941 (2005).

${ }^{42}$ Payam Akhavan, Are International Criminal Tribunals a Disincentive to Peace?: Reconciling Judicial Romanticism with Political Realism, 31 Hum. RighTs Q. 624 (2009).

${ }^{43}$ Sara McLaughlin Mitchell \& Emilia Justyna Powell, Domestic Law Goes Global: Legal Traditions AND INTERNATIONAL COURTS 196-205 (Cambridge University Press, 2011).
} 
an international institution like the ICC to influence behavior and compliance positively. Kenya is a good case to seek evidence of compliance for several reasons. First, Kenya joined the court in 2005 despite the fact that it had relatively poor human rights practices, a history of civil conflict, and slow and corrupt judicial institutions. ${ }^{44}$ This means that Kenya is a state with room to improve and where evidence of compliance or noncompliance, in terms of bettering human rights practices or protecting against impunity, may be more readily observable. Thus, although some literature expects a screening effect where "bad" states do not participate, this is a case where we can look for behavioral change related to treaty terms and goals.

Second, Kenya provides a good test of normative theories about effectiveness and compliance precisely because the ICC case was commenced by the prosecutor proprio motu. Kenya refused to self-refer its case to the ICC, meaning that it did not expressly consent to the ICC's investigation. Under such circumstances, one might expect that the ICC could have some difficulties obtaining Kenya's cooperation with future orders. Therefore, to the extent there is evidence of positive change, it may not have been wholly self-driven, but instead, may have been influenced by the ICC and its enforcement powers.

Finally, the Kenya case also provides a good test of the institutionalist hand-tying theory. Kenya was in a democratic transition at the time it joined the court, and examining the postcommitment evidence can help show whether its actions are consistent with some other domestically-driven movement for positive change relating to protections against human rights abuses. In particular, we can assess not only whether the ICC influenced any positive changes in behavior, but also whether any such changes were influenced by the type of strong civil society

\footnotetext{
${ }^{44}$ See UN Human Rights Council, Report of the Special Rapporteur on Extrajudicial, Summary or Arbitrary Executions, Addendum: Mission to Kenya, Philip Alston (May 26, 2009), at para. 23, 16-17 (calling the Kenyan criminal justice system "terrible” and indicating that judicial processes are slow and corrupt).
} 
that Simmons and Neumeyer found aided institutional effectiveness and member compliance.

\section{Methodology: Defining Compliance}

This case study examines Kenya’s actions and facts surrounding its interaction with the ICC in an effort to find evidence of whether the ICC's ostensibly strong enforcement powers are as strong in practice as they seem to be on paper. In doing so, it considers several aspects of positive influence and compliance that directly relate to the ICC's overarching goal of ending impunity for mass atrocities, as well as its processes for achieving that goal.

(a) Kenya's human rights record before and after ICC ratification. First, this study will seek evidence about whether Kenya's human rights practices have changed in any notable way since Kenya ratified the Rome Statute in 2005. Such evidence is relevant because one goal of the threat of prosecution is to deter international criminal behavior. ${ }^{45}$ In the case of the ICC, one primary way that states can avoid an ICC prosecution of their citizens is if the state's citizens do not commit serious human rights violations.

(b) Kenya's tolerance level for impunity. Second, this study will look for evidence of any notable change as it relates to Kenya's tolerance for impunity for serious human rights abuses. It seeks evidence of domestic prosecutions or other efforts to improve the domestic protections against human rights abuses—-for example, through laws or other changes to law enforcement institutions like courts and the police. Such evidence is relevant given that the ICC's stated goal is to end impunity for serious international

\footnotetext{
${ }^{45}$ Deterrence is a principle justification for international criminal law, as well as for domestic criminal justice systems. MARK A. DRUMBL, ATROCITY, PUNISHMENT, AND INTERNATIONAL LAW 169 (2007) (discussing international criminal law); Paul Robinson \& John Darley, The Role of Deterrence in the Formulation of Criminal Law Rules: At Its Worst When Doing Its Best, 91 GEO. LAW J. 949, 950-51 (2002) (discussing the primary justification for domestic criminal justice systems).
} 
crimes. Further, the ICC's complementarity provision seeks to encourage domestic prosecutions so that the court is only a last resort. States can better comply with the ICC treaty if they take measures to discourage human rights abuses through their own domestic prosecutions. Such domestic processes also signify a way in which states can comply with the treaty mandate of ending impunity for serious international crimes.

(c) Kenya's ICC compliance. Last, because Kenya is the subject of an ICC case, this study offers the possibility of seeking evidence of Kenya's compliance with specific court processes and orders relating to the case. If the ICC's enforcement powers are strong in practice, then we should see that the ICC can compel Kenya to cooperate in its investigation even though Kenya did not self-refer the case. By ratifying the Rome Statute, Kenya supposedly signaled its commitment to the court and its agreement that the court could prosecute its own citizens if Kenya failed to prosecute them on its own.

\section{KENYA: THE EVIDENCE OF (NON) COMPLIANCE}

\section{A. Have Human Rights Practices Changed Since Kenya Ratified the Rome Statute} IN 2005?

Shortly after ratification, during the 2008 presidential elections, Kenya was again engaged in mass violence that left many dead or displaced. This evidence suggests that at least in the early days, Kenya’s commitment did not also lead to compliance inasmuch as its own government was alleged to have either participated in or silently sanctioned human rights abuses against citizens.

On the other hand, some evidence indicates that the ICC's involvement with Kenya has helped make Kenya a more peaceful and stable country as related to its 2013 elections. Indeed, after the ICC prosecutor named its initial six suspects, Kenyatta and Ruto formed a political alliance within their party to run for the presidency together to defeat then-Prime Minister, Raila 
Odinga, who vocally supported the ICC processes that had commenced against his rivals. ${ }^{46}$ This alliance was unusual in that Ruto and Kenyatta allegedly incited violent attacks against the other's supporters during the 2008 elections. ${ }^{47}$ Commentators, however, suggest the partnership was a logical outcome of the ICC processes: a way for Kenyatta and Ruto to defeat both Odinga and the ICC prosecutor. ${ }^{48}$ First, the two successfully defeated a case commenced by some local non-profits in Kenya, which argued that the men should not be able to run for office because the ICC indictments showed that they did not meet new Constitutional requirements which called for public officials to have integrity. ${ }^{49}$ Kenyatta and Ruto were also successful in their presidential bid, using rhetoric about the supposed politically-motivated nature of the ICC proceedings to rally the support of their respective communities’ support (Kenyatta is Kikuyu and Ruto is Kalenjin). ${ }^{50}$ In short, the ICC indictments drove two staunch rivals to work together and to get their followers to do the same.

Not only did the ICC apparently contribute to the alliance, but it also seems to have played a large role in the peacefulness of the 2013 elections. The court went on record and warned the ICC suspects that it was prepared to issue new arrest warrants if the suspects were found making dangerous speeches that preached hatred and violence within Kenya. During a 2011 court appearance, an ICC presiding judge said that she had read "newspaper reports to the effect that

\footnotetext{
${ }^{46}$ See Hansen, supra note 22, at 18-20. See also Joan Pereruan, Hague cases set to change the 2012 election game plan, DAILY NATION (Sept. 4, 2011), http://www.nation.co.ke/News/politics/A+race+against+time+//1064/1141852/-/2ifwihz/-/index.html [http://perma.cc/LY8Q-MM75].

47 See Prosecutor's Application Pursuant to Article 58 as to William Samoei Ruto, Henry Kiprono Kosgey, and Joshua Arap Sang, Public Redacted Version of Document ICC_01/09-30-Conf-Exp, Dec. 15, 2010.

${ }^{48}$ KNDR National Dialogue and Reconciliation Monitoring Project, Draft Review Report 47 (Apr. 2011), http://www.dialoguekenya.org/docs/April2011KNDRReport.pdf [http://perma.cc/Z7CM-T323].

49 Jeffrey Gettleman, Kenyan Court Rejects Suit Against Presidential Candidate, N.Y. TIMEs (Feb. 15, 2013), http://www.nytimes.com/2013/02/16/world/africa/kenyan-court-rejects-suit-against-kenyattas-candidacy.html. [https://perma.cc/ZQZ9-P8D8].

${ }^{50}$ International Crisis Group, Kenya’s 2013 Elections (Jan. 17, 2013), at 11, 13, [hereinafter Kenya’s 2013 Elections], http://www.crisisgroup.org/ /media/Files/africa/horn-of-africa/kenya/197-kenyas-2013-elections.pdf [http://perma.cc/X47X-A9GQ].
} 
some of the suspects are engaging in hate speech which could occasion fresh chaos” and that such speeches "could be interpreted as inducement to violate the conditions set by the court and which include that the suspects should not commit fresh crimes within the jurisdiction of the court." ${ }^{51}$ At least one commentator has argued that these warnings seem to have made a positive impact, with Kenyatta and Ruto only soon thereafter preaching peace and reconciliation before the upcoming election to a domestic audience. ${ }^{52}$ Reports in a Kenyan paper state that the leaders' message was a strong break from the combative statements the two had been issuing before their initial appearance in The Hague the week before. ${ }^{53}$ Apparently, Kenyatta and Ruto continued to preach peace: news reports show that only one week before the 2013 elections, they and Odinga appeared at a prayer rally, all promising to promote non-violent elections. ${ }^{54}$

That the ICC played a significant role in contributing to Kenya's peaceful elections seems clearer when one considers other alternative explanations for the outcome. First, the evidence does not suggest that Kenyatta and Ruto were pandering to the West and preaching peace so as to obtain aid or trade or other relations. News reports indicated that the west was hoping Odinga would win the elections, and Britain stated that if Kenyatta won, it would be limiting relations with him because of his ICC indictment. ${ }^{55}$ Western states did warn Kenya that elections should be peaceful, but Kenyatta derisively dismissed those warnings. He retorted that Kenya is not keen on Western

51 Nzau Musau, ICC Warns Ocampo Six Over Hate Speech, THE STAR (Apr. 8, 2011), http://www.thestar.co.ke/news/article-67140/icc-warns-ocampo-6-over-hate-speech.

52 Hansen, supra note 22, at 26.

${ }^{53}$ William Oeri, Uhuru and Ruto vow to preach peace, DAILY NATION (Apr. 11, 2011), http://www.nation.co.ke/news/politics/Uhuru-and-Ruto-vow-to-preach-peace-/-/1064/1142960/-/7hklm3//index.html [http://perma.cc/B5KT-35C4].

${ }^{54}$ Simon Ndonga, presidential candidates promise peaceful election, AFRICA-NEWS AND ANALYSIS (Feb. 25, 2013), http://africajournalismtheworld.com/tag/kenyatta-promises-peaceful-election/ [http://perma.cc/8GNU-VQB4].

55 Alex Perry, What Uhuru Kenyatta's Victory Means for Kenya, WoRLD TIME (March 9, 2013), http://world.time.com/2013/03/09/kenyas-election-what-uhuru-kenyattas-victory-means-for-africa/ [http://perma.cc/5EWC-H6ME]. 
interference and that others, like China, are interested in business relations with Kenya. ${ }^{56}$

One cannot contribute the peace to domestic institutional changes alone. Kenya did adopt a new constitution in $2010 .{ }^{57}$ Some reports suggested that this new constitution contributed to more peaceful elections because it provided for an independent judiciary to preside over election results. As such, members of the public could feel more assured than in the past that election results would not be fraudulently manipulated by a powerful few. ${ }^{58}$ Nevertheless, there are reasons to believe that the ICC helped make that new constitution a reality. Although Kibaki's presidential promises included delivering a new constitution, the initial constitution he proposed only months after committing to the ICC in 2005 was overwhelmingly rejected because it continued to vest all powers in the executive. ${ }^{59}$ The new constitution providing for a more decentralized political system minimizing presidential power and increasing judicial independence was only delivered in $2010 .^{60}$

In sum, there is reason to conclude that the ICC and its enforcement powers positively impacted Kenya’s human rights practices by aiding in deterring an election accompanied by widespread violence. This is especially so as Kenyatta and Ruto were both associated with the authoritarian Moi regime and were viewed in the past as fueling divisive tribal politics-as opposed to unity politics. ${ }^{61}$

\footnotetext{
${ }^{56}$ If Raila Odinga Wins Kenya's elections, Britain's Interests Are Secure, But If Uhuru Kenyatta Wins . . ., THE KENYAN DAILY EXPRESS (Feb. 27, 2013), http://kenyanexpress.blogspot.com/2013/02/if-raila-odinga-wins-kenyaselections.html.[http://perma.cc/K9CP-D5CC].

${ }^{57}$ A copy of Kenya's 2010 constitution can be found at http://www.nation.co.ke/blob/view/-/913208/data/157983//18do0kz/-/published+draft.pdf.

${ }^{58}$ Herzon Ochiel and Drazen Jorgic, Peace holds in heartlands of Kenya's election losers, REUTERs, March 10, 2013, http://www.reuters.com/article/2013/03/10/us-kenya-elections-idUSBRE92907Z20130310

[http://perma.cc/GZM2-XUWC].

${ }^{59}$ See MICHELA WRONG, IT'S OUR TURN TO EAT: THE STORY OF A KENYAN WHISTLEBLOWER (Fourth Estate: London, 2009), 241-45.

${ }^{60}$ Michael Onyiego, New Constitution in Kenya Could Bring Long-Awaited Reform, VOA News.Com (Apr. 7, 2010), http://www.voanews.com/content/new-constitution-in-kenya-could-bring-long-awaited-reform90255757/159838.html [http://perma.cc/9GZ7-HJW5].

${ }^{61}$ Hansen, supra note 22, at 30.
} 


\section{B. How TOLERANT IS KENYA OF IMPUNITY?}

This section considers whether and to what extent the ICC has impacted Kenya's commitment to ending impunity for serious international crimes. Evidence on the whole suggests that Kenya has not meaningfully altered its previous culture of impunity. As the above description of Kenya's initial behavior in response to the 2008 post-election violence shows, Kenya did not seem keen on investigating and prosecuting perpetrators. The ICC investigation commenced because Kenya many times failed to establish a domestic tribunal. In its admissibility challenge to the ICC, Kenya did claim that it was investigating the post-election violence. The Pre-Trial Chamber, however, found that Kenya had not commenced any domestic proceedings against persons bearing the greatest responsibility for the violence, but instead had commenced only a limited number of cases for minor crimes, such as for theft or housebreaking. ${ }^{62}$ The Appeals Chamber later upheld the Pre-Trial Chamber’s decision. ${ }^{63}$

Recent reports indicate that Kenya’s government has still made no real efforts to establish domestic mechanisms to deliver justice to victims of the post-election violence by holding perpetrators accountable. ${ }^{64}$ As of 2014 , only twenty-four suspects had been convicted out of more than 6,000 cases that had been pending for potential domestic prosecution. ${ }^{65}$ Moreover, in February 2014, the Office of the Director of Public Prosecutions declared that 4,000 cases were being dropped as they were impossible to prosecute. ${ }^{66}$ In 2008, the government established a Truth

\footnotetext{
${ }^{62}$ ICC Pre-Trial Chamber II, Decision Pursuant to Article 15 of the Rome Statute on the Authorization of an Investigation into the Situation in the Republic of Kenya, (March 31, 2010), ๆๆ 183-86, http://www.icccpi.int/iccdocs/doc854287.pdf [https://perma.cc/HU5A-YFB4].

${ }^{63}$ Prosecutor v. Ruto, Kosgey \& Sang, Case No. ICC-01/09-01/11 A, Judgment on the Appeal of the Republic of Kenya Against the Decision of Pre-Trial Chamber II of 30 May 2011 Entitled "Decision on the Application by the Government of Kenya Challenging the Admissibility of the Case Pursuant to Article 19 (2)(b) of the Statute" (Aug. 30, 2011), I 46, http:/www.icc-cpi.int/iccdocs/doc/doc1223134.pdf [http://perma.cc/7EWF-TH2B].

${ }^{64}$ Kenyan Human Rights Commission, Kenya: One Year in Office for Uhuru Kenyatta and William Ruto, at 13.

${ }^{65} \mathrm{Id}$.

${ }^{66}$ Id. See also Luke Moffett, After the collapse of the Kenyatta case, how is the ICC supposed to help victims?, THE
} 
Justice and Reconciliation Commission (TJRC) as part of the process immediately following the post-election violence. Then in May 2013, the TJRC delivered a final report to President Kenyatta. However, as of December 2014, the government has not implemented the TJRC's recommendations. ${ }^{67}$

Nor has Kenya embraced the ICC processes as a way to insure accountability and end impunity. Immediately after the six suspects were named, Kenya's parliament voted to have Kenya withdraw from the ICC. ${ }^{68}$ Although Kenya did not withdraw at that time, it continued to try to stop the ICC from proceeding. After obtaining African Union support, Kenya lobbied the United Nations Security Council to defer the ICC cases. ${ }^{69}$ After the Security Council refused the requested deferral, Kenya then filed its admissibility challenge, which the court rejected. ${ }^{70}$

As the cases neared trial, Kenya continued to fight the ICC processes. In May 2013, Kenya submitted a paper to the African Union urging it to help persuade the ICC to terminate the cases against Kenyatta and Ruto or refer the cases to Kenya for consideration, citing the country's new constitution and reformed judiciary. ${ }^{71}$ Kenyatta himself spoke at the African Union Summit in

CONVERSATION (Dec. 10, 2014), http://theconversation.com/after-the-collapse-of-the-kenyatta-case-how-is-the-iccsupposed-to-help-victims-34991 [http://perma.cc/2R5T-EF3Y];, Response to Ambassador Macharia Kamau's Statement KenYANS FOR PEACE With TRUTH AND Justice (Nov. 10, 2014), http://www.iccnow.org/documents/KPTJ_Response_to_Kenya_UNGA_Statement_on_ICC.pdf [http://perma.cc/J3XD-2MZT].

${ }^{67} \mathrm{Id}$.

${ }^{68}$ Michael Onyiego, Kenya's Politicians Look to Withdraw from ICC as Suspects Named, VOA NEWS.COM (Dec. 16, 2010), http://www.voanews.com/content/kenyas-politicians-look-to-withdraw-from-icc-as-suspects-named-111998579/157058.html [http://perma.cc/2YSZ-U7MT].

${ }^{69}$ Emeka-Mayaka Gekara, Kenyan security chiefs’ bid to suspend Ocampo probe fails, DAILY NATION (Feb. 2, 2011), http://www.nation.co.ke/news/Kenyan-security-chiefs--bid-to--suspend-Ocampo-probe-fails-//1056/1100576/-/baxcam/-/index.html.

${ }^{70}$ Michael Onyiego, Kenya Seeks Another Way to Stall Hague Proceedings, VOA NEWS.COM (March 21, 2011), http://www.voanews.com/content/kenyaseeksanotherwaytostallhagueproceedings118352894/136823.html [http://perma.cc/FX4B-5C7S].

${ }^{71}$ ICC: Kenya seeks Africa’s support, New ZIMBABWE (May 23, 2013), http://www.newzimbabwe.com/news11190ICC+Kenya+seeks+Africa\%E2\%C3\%AF\%C2\%BF\%C2\%BD\%C3\%AF\%C2\%BF\%C2\%BDs+support/news. aspx [http://perma.cc/Q6FS-T8P6]. 
May 2013, accusing the ICC of bias and racism. The outcome of that Summit included an African Union call to halt the ICC case against Kenyatta and any sitting presidents going forward. ${ }^{72}$ In September 2013, Kenya’s parliament again voted to withdraw from the ICC. ${ }^{73}$

Though Kenya still has not withdrawn, it has also not stopped its efforts to halt the ICC processes. In November 2013, Kenya informed the United Nations that it would be seeking an amendment to the Rome Statute that would provide immunity from prosecution to sitting heads of state. ${ }^{74}$ In only October 2014, Kenya's ambassador to the United Nations made a speech to the assembled parties arguing that the ICC is being manipulated by a pernicious group of countries of an imperialist nature who are targeting Africa. As to the Kenya cases, in particular, the ambassador claimed that the ICC cases were hindering domestic efforts at reconciliation. ${ }^{75}$ As mentioned above, in December 2014, the ICC dropped its case against Kenyatta, with the prosecutor arguing that Kenya's lack of cooperation with the court and interference with witnesses had made it impossible for her to prove the charges beyond a reasonable doubt. ${ }^{76}$

Nevertheless, there have been some positive developments on the domestic front regarding institutional mechanisms to address criminal behavior, and hence, the fight against impunity. Since joining the ICC, Kenya has adopted a new constitution, implemented the 2009 International Crimes Act criminalizing domestically the crimes within the jurisdiction of the ICC, and improved

\footnotetext{
${ }^{72}$ African Union Urges ICC to Deter Uhuru Kenyatta Case, BBC NEws (Oct. 13, 2013), http://www.bbc.com/news/world-africa-24506006 [http://perma.cc/NXZ3-S4S5].

${ }^{73}$ MG Zimeta, What Kenya's withdrawal means for the international criminal court, THE GUARDIAN (Sept. 6, 2013), http://www.theguardian.com/commentisfree/2013/sep/06/kenya-withdrawal-icc-credibility.

${ }^{74}$ Moses Michira, We Have Already Sent Ammendment to UN, Says Amina, StANDARd Digital (NOV. 23, 2013), http://www.standardmedia.co.ke/thecounties/article/2000098450/we-have-already-sent-ammendment-to-un-saysamina [https://perma.cc/6L77-D5RV?type=source].

${ }^{75}$ Kevin J. Kelley, Kenya's UN Envoy Launches Stinging Attack on ICC, DAILY NATION (Nov. 1, 2014), http://www.nation.co.ke/news/Kenya-UN-envoy-launches-stinging-attack-on-ICC/-/1056/2507206/-/ipvbfaz//index.html [http://perma.cc/6F85-YPVM].

${ }^{76}$ Peter Cluskey, Victims and International Criminal Court biggest losers as Kenyatta trial collapses, IRISH TIMES (Dec. 16, 2014).
} 
the functioning of its judiciary and police. ${ }^{77}$ And there are reasons to believe the presence of the ICC is, at least in part, responsible for prompting these developments. ${ }^{78}$ As noted above, although Kenya was on an apparent path towards democratizing with the election of Kibaki, the key constitutional component was only implemented well after the commencement of the ICC processes. ${ }^{79}$ Similarly, although Kenya could have passed a domestic law criminalizing the ICC crimes before or at the time of its ratification, it only did so after the world community threatened to step in with an ICC case after the 2008 post-election violence.

These positive developments, however, do not change that in practice, as opposed to on paper, Kenya's culture of impunity—at least as to those in power—seems little changed. The weight of the evidence indicates that Kenya has done very little to hold perpetrators of the 2008 post-election violence accountable. Further, reports indicate that other accountability gaps remain. Allegations suggest that the security services are involved in disappearances and extrajudicial executions. There are also complaints regarding high-level corruption in the security services. ${ }^{80}$

\section{Has Kenya Complied With ICC Processes ANd Orders?}

There is evidence that Kenya has been less than compliant with the ICC. Much evidence suggests that the ICC's enforcement powers have not been sufficient to compel Kenya to cooperate with the ICC’s investigation or court processes.

The suspects in the Kenya case voluntarily answered the ICC summons against them and

\footnotetext{
${ }^{77}$ Wanyeki, supra note 19, at 17-18.

${ }^{78} \mathrm{Id}$. at 17 (stating that the ICC has clearly helped produce constitutional, legal, and institutional reforms).

${ }^{79}$ The story is similar with respect to the 2009 International Crimes Act. Kenya joined the court in 2005, yet it only implemented the legislation to enable it to domestically prosecute the crimes within the court's jurisdiction after the threat of ICC intervention. That law, of course, only applies to crimes committed after its implementation, meaning that it cannot be used to prosecute the 2008 post-election violence cases domestically.

${ }^{80}$ Wanyeki, supra note 19, at 18.
} 
appeared in The Hague. ${ }^{81}$ This initially seemed like a good omen and one that might indicate a future of cooperation. In fact, President Kenyatta is the first sitting head of state to appear before the ICC. ${ }^{82}$ Other suspects, like President Bashir, have evaded arrest for many years. On the other hand, as some commentators have noted, the decision to willingly appear before the court may constitute nothing more than a "veneer" of cooperation. ${ }^{83}$ By publicly cooperating with the ICC, Kenyatta can purport to be on the right side of justice, rather than an alleged war criminal like President Bashir. ${ }^{84}$ By publicly cooperating, Kenyatta could minimize the risk to trade and diplomatic relations. ${ }^{85}$

The evidence does show that Kenyatta has succeeded in being treated very differently from Bashir. For example, Britain, an ICC member state, initially threatened that because Kenyatta was an ICC indicted suspect, the country would limit itself to "essential contact" with him if he won the presidential election. Britain, however, soon reversed itself and invited Kenyatta to a conference in Somalia. ${ }^{86}$ Kenyatta was also received at the White House while under indictment for committing crimes against humanity. ${ }^{87}$ Further, there is no evidence that he or his country have

\footnotetext{
${ }^{81}$ See Coalition for the International Criminal Court, Cases \& Situations: Kenya, http://www.iccnow.org/?mod=kenya\&idudctp=20\&show=all.

${ }^{82}$ Kenyatta appears at ICC in Hague for landmark hearing, MALAwI 24 (Oct. 8, 2014), http://malawi24.com/kenyatta-appears-at-icc-in-hague-for-landmark-hearing/ [https://perma.cc/QXN5W9PR?type=source].

${ }^{83}$ See David Bosco, How to Destroy the International Criminal Court From Within, ForeIGN Policy (Oct. 10, 2014), http://foreignpolicy.com/2014/10/10/how-to-destroy-the-international-criminal-court-from-within/ [http://perma.cc/55HY-HLLA].

${ }^{84}$ Karen J. Alter, The trials and tribulations of prosecuting heads of states: Kenyatta and the ICC, Monkey Cage Blog, WASH. POST (Dec. 23, 2014), http://www.washingtonpost.com/blogs/monkey-cage/wp/2014/12/19/the-trialsand-tribulations-of-prosecuting-heads-of-states-kenyatta-and-the-icc/ [http://perma.cc/S58M-XFTX].

${ }^{85}$ See Kenya's 2013 Elections, supra note 50, at 18.

${ }^{86}$ Geoffrey York, How Kenya is defying the Hague, THE GLOBAL MAIL (May 26, 2013), http://www.theglobeandmail.com/news/world/how-kenya-is-defying-the-hague/article12161678/ [http://perma.cc/C5W2-4PW5].

${ }^{87}$ Press Release, U.S. President Obama and First Lady Greet President Kenyatta, (Aug. 5, 2014), EMBASSY OF THE UNITED STATES, http://nairobi.usembassy.gov/pr-080514.html [http://perma.cc/TWA9-FXMH].
} 
been targeted with economic sanctions. ${ }^{88}$

What of the less public evidence? That evidence suggests that Kenya and Kenyatta have been covertly sabotaging the ICC's efforts to prosecute the Kenyan suspects. ${ }^{89}$ Evidence even at the start of the ICC's investigation suggested that Kenya was not fully cooperating with efforts to gather evidence. ${ }^{90}$ The evidence of a lack of cooperation has only mounted over time, such that ICC Prosecutor Bensouda has called it “unprecedented.” She says that because Kenya has failed to turn over cell phone and financial information, it showed the link between the president and the gangs behind the post-election violence. ${ }^{91}$ She charges that witnesses have "disappeared” or been bribed so as to withdraw. ${ }^{92}$ Witnesses have also stated that they were concerned of their safety if they testified. ${ }^{93}$ The ICC even issued an arrest warrant for Kenyan journalist, Walter Barasa, for allegedly participating in the bribery and intimidation. ${ }^{94}$ The defense disavowed the accusations of witness tampering, claiming instead that witnesses were being coached. ${ }^{95}$ In any event, the ICC dropped the case against Kenyatta. The prosecutor said the decision was not for the reasons stated

\footnotetext{
${ }^{88}$ Apparently, the EU is a large donor and big importer of Kenyan produce, and the US gives Kenya about $\$ 900$ million per year in aid. David Smith, Uhuru Kenyatta inauguration and the inconvenient ICC truth, THE GUARDIAN (Apr. 9, 2013), http://www.theguardian.com/world/2013/apr/09/uhuru-kenyatta-inauguration-icc [http://perma.cc/P5L4-HEF4].

${ }^{89}$ Alter, supra note 84.

${ }_{90}^{90}$ Michael Onyiego, Legal Challenges Threaten to Undermine ICC Investigation in Kenya, VOA NEWS.COM (Oct. 4, 2010), http://www.voanews.com/content/legal-challenges-threaten-to-undermine-icc-investigation-inkenya-104287214/155957.html [http://perma.cc/2X3J-7ZUY].

${ }^{91}$ Cluskey, supra note 76.

${ }^{92}$ See Natalie Ojweska, Uhuru Kenyatta's trial, A case study in what's wrong with the ICC (Feb. 6, 2014), http://www.globalpost.com/dispatch/news/regions/africa/kenya/140206/uhuru-kenyattas-trial-case-study-whatswrong-the-icc (quoting the ICC Prosecutor talking about Kenya’s witness tampering practices).

${ }^{93}$ Smith, supra note 88. See also Alter, supra note 84.

${ }^{94}$ Press Release, Arrest Warrant Unsealed in Kenya situation: Walter Barasa suspected of corruptly influencing witnesses (Feb. 10, 2013), http://www.icc-

cpi.int/en_menus/icc/press\%20and\%20media/press\%20releases/Pages/pr948.aspx [https://perma.cc/9ZXUCEB7?type $=$ source $]$.

${ }^{95}$ Adam Taylor, Why Kenya's president came to the International Criminal Court-and why that's a problem for the ICC, WASH. POST (Dec. 16, 2014), https://www.washingtonpost.com/news/worldviews/wp/2014/10/08/whykenyas-president-came-to-the-international-criminal-court-and-why-thats-a-problem-for-the-icc/ [https://perma.cc/Q4YR-42M5].
} 
by the Kenyan government, namely that Kenyatta was innocent. Rather, she stated that Kenya breached its treaty obligations under the Rome Statute by obstructing her investigation. ${ }^{96}$

\section{CONCLUSIONS AND IMPLICATIONS}

The evidence outlined above does suggest that the ICC’s enforcement powers in practice are not strong enough to compel compliance with either treaty terms or individual court orders. Kenya continues to generally adhere to a culture of impunity. Further, Kenya, for the most part, seems to have managed to keep the ICC from obtaining the evidence it needed to proceed against some of the suspects. This means that some individuals who have allegedly committed crimes against humanity will go free and will not face justice. Thus, in some respects, the Kenya case study confirms what other studies have concluded; that international human rights treaties are not necessarily effective at constraining states that commit human rights abuses such that they are induced to comply with treaty terms.

However, the case study has also produced some evidence consistent with the studies that suggest the ICC may have a more positive influence on state conduct than treaties with weaker enforcement mechanisms. Most importantly, the evidence indicates that the ICC played a significant role in producing elections in 2013 that were generally peaceful and not accompanied by the kind of ethnically-charged violence that has historically accompanied Kenyan elections. Specifically, the evidence shows that Kenyatta and Ruto preached peace after the ICC judge went on the record reminding them that hate speech could lead to additional charges. Recall that Kenyatta and Ruto are from different tribes and were each accused of instigating tribal violence in the aftermath of the 2007 elections. But they later found common ground: attacking the ICC in an effort to both insure their elections and defeat the ICC cases against them. This suggests that the

\footnotetext{
${ }^{96}$ Cluskey, supra note 76.
} 
spotlight of the ICC helped to prevent deaths and other violence like that associated with past elections. Kenyatta has managed to escape trial, and Ruto may also manage the same. But if the threat of additional charges for openly inciting violence helped to save hundreds of potential lives, then maybe the ICC has been effective in some meaningful way.

Given that the evidence of compliance or non-compliance is equivocal, what does this mean for the likely future of the prosecutor's proprio motu powers? Some commentators, such as Professor David Bosco, suggests that the Kenyatta case has damaged the court in lasting ways that may affect future decisions about whether to invoke the proprio motu power to investigate. ${ }^{97}$ Professor Bosco argues that Kenyatta has written the model on impunity and demonstrated how others could similarly avoid a successful proprio motu prosecution by outwardly appearing to cooperate, while obstructing the prosecutor behind the scenes. ${ }^{98}$

Bosco may be right, but does this mean that the proprio motu power is so damaged that it cannot be a useful tool to demand compliance with treaty terms and positively impact behavior in the future? This Article concludes that there are reasons to answer this question in the negative. First, the Kenya case was the prosecutor's first use of proprio motu powers, and moreover, the court itself is in its infancy. It is bound to have some growing pains. It can learn from its experiences and seek out ways to insure its tools are more effective in the future. Second, as Professor Karen Alter argues, even if Kenyatta did write the manual on impunity, not all leaders will have the same "skill or political cache to carry off a repeat story." ${ }^{99}$ Among other things, Kenyatta is the son of Kenya's first president, groomed from childhood for political office, and his family's business empire is so large that it can influence the personal future of many Kenyans (for

\footnotetext{
${ }^{97}$ Bosco, supra note 83.

${ }^{98} \mathrm{Id}$.

${ }^{99}$ Alter, supra note 84.
} 
example, potential witnesses). In fact, Kenyatta is the richest person in Kenya. ${ }^{100}$ Moreover, Kenyatta is a popular leader who also was careful not to repeat behavior that led to his indictment by preaching peace. ${ }^{101}$ The court may be able to better enforce compliance in other cases where the leaders are less astute, well-liked, or powerful.

This is not the first time a court has been faced with defendants who seek to obstruct justice or tamper with witnesses. In fact, the International Criminal Tribunal for Rwanda had similar difficulties getting Rwanda to cooperate and allow witnesses to testify at various proceedingseven though the United Nations Security Council created the tribunal and could ostensibly compel cooperation. ${ }^{102}$ One way to ensure that the proprio motu powers are as strong in practice as they are in paper is to have the states that have committed to the court actually support the prosecutor's efforts. As Bosco notes, however, “[t]he course of the Kenyatta investigation ... suggests that the court's most enthusiastic backers—including those in Europe-have not exerted enough political pressure on Kenya to work with the court.” ${ }^{103}$ Indeed, states use a variety of tools to get other states to yield to their demands: they threaten or impose economic sanctions, or they threaten to cut off military or economic aid. The United States used just such tools under the Bush administration in order to convince other states to sign bilateral agreements precluding the state from surrendering American officials or military personnel to the court. ${ }^{104}$ Though some states refused to sign those agreements, more than 100 succumbed to the pressure. ${ }^{105}$ Not all states will have the same resources to exert such pressure. On the other hand, states that have joined the court

\footnotetext{
100 Perry, supra note 55.

101 Alter, supra note 84.

102 See ViCTOR PESKin, InTERnATIONAL JUSTICE IN RAWANDA AND THE BALKANS 187-88, 212-13 (2008).

103 Bosco, supra note 83.

104 The United States refused military assistance to States Parties to the ICC that refused to sign bilateral immunity agreements.

105 The website for the Coalition for the International Criminal Court lists the states that had signed bilateral immunity agreements with the United States as of 2006. See Status of Bilateral Immunity Agreements, http://www.iccnow.org/documents/CICCCFS_BIAstatus_current.pdf.
} 
should at least assess what leverage they do have and exert it so that the ICC has an opportunity to fulfill its mandate—rather than, for instance, inviting an indicted president to visit their country. We may never know with certainty whether Kenya tampered with witnesses. But, going forward, states parties could take a greater interest in determining the facts about a defendant's level of cooperation and then make it known that they are prepared to insist on cooperation by instituting some type of sanction. No institution's powers in practice are likely to equal those it possesses on paper unless it receives some backing. In this case, the police force that must back up the ICC is its member states. Otherwise, they too, are failing to live up to their obligations. 